OPEN ACCESS

Edited by:

Reinhold J. Medina,

Queen's University Belfast,

United Kingdom

Reviewed by:

Chad L. Barber,

California Lutheran University,

United States

Kazuhide Hayakawa,

Massachusetts General Hospital,

United States

${ }^{*}$ Correspondence:

Victor W. M. van Hinsbergh

v.vanhinsbergh@vumc.nl

tThese authors have contributed equally to this work

Specialty section

This article was submitted to

Translational Medicine,

a section of the journal

Frontiers in Medicine

Received: 18 June 2018 Accepted: 06 December 2018 Published: 20 December 2018

Citation:

Tasev D, Dekker-Vroling L, van Wijhe M, Broxterman $H J$, Koolwijk $P$ and van Hinsbergh WWM

(2018) Hypoxia Impairs Initial Outgrowth of Endothelial Colony Forming Cells and Reduces Their Proliferative and Sprouting Potential.

Front. Med. 5:356

doi: 10.3389/fmed.2018.00356

\section{Hypoxia Impairs Initial Outgrowth of Endothelial Colony Forming Cells and Reduces Their Proliferative and Sprouting Potential}

\author{
Dimitar Tasev ${ }^{1 \dagger}$, Laura Dekker-Vroling ${ }^{2 \dagger}$, Michiel van Wijhe ${ }^{1}$, Henk J. Broxterman ${ }^{2}$, \\ Pieter Koolwijk ${ }^{1}$ and Victor W. M. van Hinsbergh ${ }^{1 *}$
}

1 Department of Physiology, Amsterdam Cardiovascular Sciences, Amsterdam University Medical Centers, Amsterdam, Netherlands, ${ }^{2}$ Department of Medical Oncology, Amsterdam University Medical Centers, Amsterdam, Netherlands

Vascular homeostasis and regeneration in ischemic tissue relies on intrinsic competence of the tissue to rapidly recruit endothelial cells for vascularization. The mononuclear cell (MNC) fraction of blood contains circulating progenitors committed to endothelial lineage. These progenitors give rise to endothelial colony-forming cells (ECFCs) that actively participate in neovascularization of ischemic tissue. To evaluate if the initial clonal outgrowth of ECFCs from cord (CB) and peripheral blood (PB) was stimulated by hypoxic conditions, MNCs obtained from CB and PB were subjected to 20 and $1 \%$ $\mathrm{O}_{2}$ cell culture conditions. Clonal outgrowth was followed during a 30 day incubation period. Hypoxia impaired the initial outgrowth of ECFC colonies from $\mathrm{CB}$ and also reduced their number that were developing from PB MNCs. Three days of oxygenation $\left(20 \% \mathrm{O}_{2}\right)$ prior to hypoxia could overcome the initial CB-ECFC outgrowth. Once proliferating and subcultured the CB-ECFCs growth was only modestly affected by hypoxia; proliferation of PB-ECFCs was reduced to a similar extent (18-30\% reduction). Early passages of subcultured CB- and PB-ECFCs contained only viable cells and few if any senescent cells. Tube formation by subcultured PB-ECFCs was also markedly inhibited by continuous exposure to $1 \% \mathrm{O}_{2}$. Gene expression profiles point to regulation of the cell cycle and metabolism as major altered gene clusters. Finally we discuss our counterintuitive observations in the context of the important role that hypoxia has in promoting neovascularization.

Keywords: ECFCs, hypoxia, colony growth, angiogenesis, tissue repair, proliferation

\section{INTRODUCTION}

The majority of wounds heal through physiological tissue repair. But if tissue repair fails, tissue engineering or regenerative medicine and transplantation is necessary (1). One of the problems during regenerative medicine is that oxygen diffusion is limited in a cellular tissue-engineered scaffold (2), resulting in reduced (hypoxia) or lack of oxygen (anoxia) within the deeper regions of the scaffold and finally cell death $(2,3)$. Therefore, it is important either to prevascularize tissue-engineered scaffolds by generating a blood vessel network in a scaffold in vitro or to create a scaffold with an environment (matrix composition, incorporation of blood vessel-generating cells and growth factors) that facilitates rapid angiogenesis when implanted in the body (4-7). 
The primary vector of angiogenesis is the endothelial cell. However, in many disease conditions or after implantation of an engineered graft the ability of the endothelium to generate new vessels proceeds too slowly to overcome tissue hypoxia and subsequent cell death. As initially shown by Asahara et al. (8), within the blood the mononuclear cell (MNC) fraction expressing CD34 contains a subset of circulating progenitors committed to endothelial lineage, which proliferate at a high rate and contribute to an accelerated assembly of a new vascular network. Subsequent studies showed that the cells originally identified as endothelial progenitor cells harbored various cell types, in particular myeloid cells that acquired endothelial marker properties and endothelial colony-forming cells (ECFCs), that actively participate in neovascularization (9-13). ECFCsalso called blood-originated endothelial cells (BOECs) - exhibit high proliferative and colony-forming ability, do belong to the endothelial cell lineage and not to the hematopoietic cell lineage, and possess robust in vitro and in vivo neovascularization ability including participation in the lining of new vessels $(9,14)$.

Low oxygen tension in ischemic tissues determinates the fate and proliferation of progenitor or stem cells (15-17). On the one hand, hypoxia can limit growth in stem cell niches (18, 19). On the other hand, a hypoxic environment can enhance recruitment of circulating angiogenesis promoting cells, e.g., via the chemokine SDF-1 $(20,21)$. One may anticipate that ECFCs proliferation is also increased in hypoxic conditions, as there is a need for cells to enable expansion of the new vascular bed. However, a number of studies demonstrated that the proliferation of ECFCs was markedly inhibited by hypoxia (22-25), although some controversy exists $(26,27)$. Hypoxia also reduced ECFC migration as well as tubule formation into matrigel (22-25), although Decaris et al., (23) reported a difference in effect between acute and chronic hypoxia. The effect of hypoxia was mimicked by the $\alpha$-ketoglutarate homolog dimethyl-oxo-glutarate (DMOG) supporting a role for HIF stabilization (24). However, the role of HIF has been debated. When the HIF- $1 \alpha$, one of the hypoxia-inducible factor $\alpha$-subunits in endothelial cells, was overexpressed in CB-ECFCs, Kütscher et al. (28) observed improved proliferation, reduced apoptosis and increased sprouting. In contrast, recently, $\mathrm{He}$ et al. (21) reported that continued hypoxia reduced the proliferation of peripheral blood (PB) ECFCs by HIF-1 $\alpha$-mediated signaling. This differs from microvascular endothelial cells in which sprouting is enhanced by HIF- $1 \alpha$, while HIF- $2 \alpha$ facilitates stabilization of vascular structures $(29,30)$.

In this study we summarize our findings on the effects on hypoxia on ECFCs using a custom designed hypoxia work station, which allows handing of the cells over longer periods in a defined oxygen atmosphere (30). Initially, we investigated the clonal outgrowth of ECFCs from human cord- and peripheral blood under hypoxic conditions. Subsequently, we evaluated the effect of various oxygen concentrations on the proliferation of $\mathrm{CB}$ - and PB-ECFCs that were cultured in the presence of platelet lysate, which improved serial propagation of ECFCs (31). Finally, we determined the effect of hypoxia on tubule formation in a fibrin matrix and compared its effect on gene expression in basal and tubule formation-stimulating conditions.

\section{MATERIALS AND METHODS Isolation of CB and PB-ECFCs Under Hypoxia and Normoxia}

The study was executed in accordance with the Declaration of Helsinki and was approved by the University Human Subjects Committee of the VU University Medical Center. Written informed consent was obtained from all donors in accordance with the institutional guidelines. CB-ECFCs and PB-ECFCs were isolated as previously described with minor modifications (32). Namely, after isolation of MNCs by Ficoll-Paque density gradient centrifugation, the $\mathrm{CB}$ - and $\mathrm{PB}$-derived MNCs were re-suspended in complete EBM-2 (Lonza, Walkersville, MD, United States) supplemented with $10 \%$ FBS, $0.1 \%$ penicillinstreptomycin, $2 \mathrm{mM}$ L-glutamine, and EGM-2 SingleQuotes (without hydrocortisone and gentamycin/ amphotericin-B). MNCs were divided in two equal inoculation parts and seeded in a density of at least $2.5 \times 10^{6}$ cells per $\mathrm{cm}^{2}$ onto $0.1 \%$ gelatin (Sigma) pre-coated 6- or 48-well plates. One culture was placed at $20 \% \mathrm{O}_{2} / 5 \% \mathrm{CO}_{2}$ and the second inoculum at $1 \% \mathrm{O}_{2} / 5 \% \mathrm{CO}_{2}$ atmosphere.

For optimal evaluation of hypoxic conditions cells were cultured inside a custom-designed hypoxia workstation (T.C.P.S., Rotselaar, Belgium) as previously described (30).

After 3 days, the medium was renewed for the first time, followed by daily renewals during the first week; from day 7 until the end of primary culture the medium was changed every other day.

The renewal medium that was used for the CB- and PBMNCs cell cultures at $1 \% \mathrm{O}_{2}$ was pre-incubated as a thin layer $\left(2 \mathrm{ml} / 10 \mathrm{~cm}^{2}\right)$ in empty culture dishes in the hypoxiachamber for at least $2 \mathrm{~h}$ in order to allow the medium to become fully hypoxic. Renewal of cell culture medium was performed within the hypoxia-chamber preventing the cells being exposed to a normoxic environment. The outgrowth of primary ECFC colonies was monitored daily and counted in the appropriate oxygen environment by phase contrast microscopy on the basis of their characteristic endothelial cobblestone morphology (Figure 1).

Endothelial phenotype of the ECFCs obtained from primary cultures at 20 and $1 \% \mathrm{O}_{2}$ was confirmed using immunofluorescence and flow cytometry as previously described (31). Flow cytometry showed that both CB-ECFCs and PB-ECFCs were positive for CD31, CD105, CD146, VEGFR2 (CD309), and negative for CD14, CD45, and CD133 $(33,34)$. Expression of CD34 was highest in dense cultures (34). In addition, the CB- and PB-ECFCs stained positive for VE-cadherin, von Willebrand factor and Acetyl-LDL uptake.

To determine the minimal exposure time to $20 \% \mathrm{O}_{2}$ needed for overcoming the lack of colony outgrowth in $1 \% \mathrm{O}_{2}, \mathrm{CB}$ MNCs of three different donors were isolated and plated in individual 6-well plates which were transferred after 24, 48, 72, or $96 \mathrm{~h}(24,48,72$, and $96 \mathrm{~h})$ from $20 \% \mathrm{O}_{2}$ to $1 \% \mathrm{O}_{2}$. Cells cultured only in $20 \% \mathrm{O}_{2}$ or $1 \% \mathrm{O}_{2}$ served as controls (T0). ECFC colonies were quantified when the colonies had become visible in the culture in $20 \% \mathrm{O}_{2}$ (maximal evaluation period of 4 weeks). All 

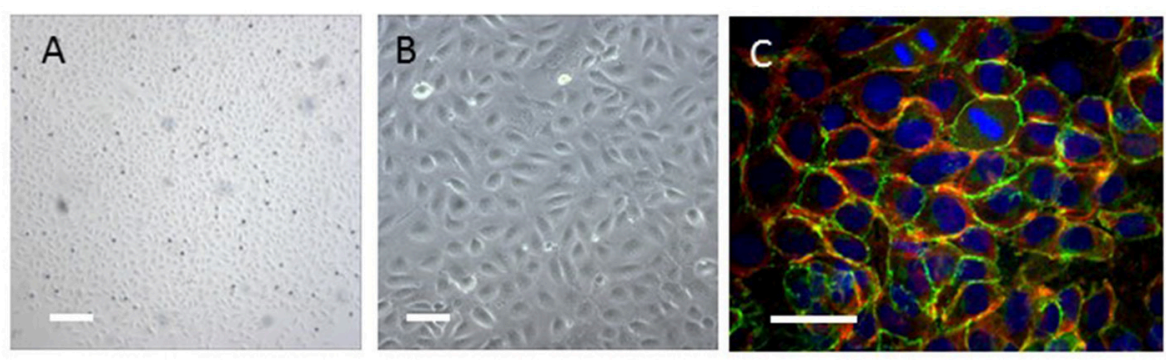

D Primary CB-ECFC colonies

E Primary PB-ECFC colonies
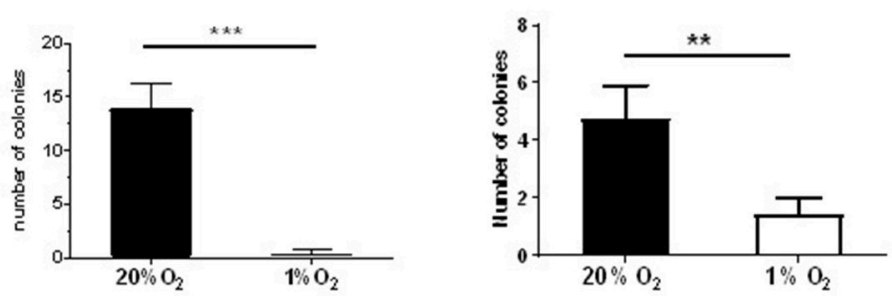

FIGURE 1 | Inhibition of clonal outgrowth of ECFCs from cord and peripheral blood MNCs by hypoxia. (A,B) Primary colony of CB-ECFCs isolated at $1 \%$ of oxygen. Bars are $500 \mu \mathrm{m}$ (A) and $100 \mu \mathrm{m}$ (B), respectively. (C) Staining of VE-cadherin (green), f-actin (red), and nuclei (DAPI) of a primary colony of CB-ECFCs. Note two dividing cells in the middle top part. Bar $=100 \mu \mathrm{m}$ (D) Enumeration of outgrowth colonies from umbilical cord blood-derived MNCs at 20 and $1 \% \mathrm{O}_{2}$ expressed as average number \pm SEM $(n=14)$ of counted colonies per donor. Statistical significance was determined by Wilcoxon matched-pairs signed rank test; ${ }^{\star \star \star} p<0.005$. (E) Enumeration of outgrowth colonies from peripheral blood-derived MNCs at 20 and $1 \% \mathrm{O}_{2}$ expressed as average number \pm SEM $(n=9)$ of counted colonies per donor. Statistical significance was determined by Wilcoxon matched-pairs signed rank test; ${ }^{* *} p<0.01$.

experiments were performed with passage 2 (proliferation assay) to passage 5 (RNAseq experiments) CB-ECFCs or PB-ECFCs.

\section{Western Blot Analysis for HIF-1 $\alpha$ and HIF-2 $\alpha$}

Subcultured CB-ECFCs were seeded on $5 \mathrm{~cm}^{2}$ dishes coated with $0.1 \%$ gelatin. The dishes were placed in $1 \% \mathrm{O}_{2}$ for various time periods $(0,3,6,24,48$, and $96 \mathrm{~h})$. The CB-ECFCs were washed with PBS and were lysed with $100 \mu \mathrm{l}$ Laemmli sample buffer (including $\beta$-mercaptoethanol, Biochemical, 1:20). The samples were heated for $5 \mathrm{~min}$ at $96^{\circ} \mathrm{C}$ and briefly centrifuged before loading. Equal volumes of samples were loaded for separation of HIF- $1 \alpha$ and HIF- $2 \alpha$ via $6 \%$ SDS-PAGE using a semi-dry transfer system (Biorad, Veenendaal, Netherlands). Rabbit polyclonal antibody HIF-1 $\alpha$ (1:250, Cayman chemical, Ann Arbor, MI, United States) and rabbit polyclonal antibody HIF-2 $\alpha$ (1:250, Novus Biologicals, Edinburgh, United Kingdom) and $\beta$-actin (Sigma-Aldrich, St Louis, MO, United States) were used as primary antibodies. Horse-radish peroxidase coupled anti-rabbit was used as a secondary antibody (1:250, DakoCytomation, Neverlee, Belgium).

\section{Transfection of CB-MNCs With dssiRNA HIF- $1 \alpha$ and HIF- $2 \alpha$}

Freshly isolated CB-MNCs were transfected with dssiRNA HIF$1 \alpha$ and HIF-2 $\alpha$ (Qiagen, Venlo, Netherlands) using 'Human monocyte nucleofactor kit' (Lonza, VPA-1007). Briefly, for each condition an equal amount of CB-MNCs was centrifuged, and
$100 \mu \mathrm{l}$ nucleofactor was added to the cell pellet. From both dssiRNA HIF- $1 \alpha$ and HIF- $2 \alpha, 1 \mu \mathrm{g}$ was added to the cell suspension, and transferred to the cuvette and placed in the electroporation system (Amaxa, Lonza Verviers) according to the manufacturer. Transfected CB-MNCs were resuspended in complete EGM medium, transferred to $0.1 \%$ gelatin coated wells, and further cultured under $1 \% \mathrm{O}_{2}$ according the CB-ECFC culture protocol. Mock transfected cells (only electroporation step, no dssiRNA transfection) served as a control in 20 and $1 \%$ $\mathrm{O}_{2}$. Further details are given in Nauta et al. (30).

\section{Assessment of Proliferative Capacity of CB- and PB-ECFCs at 20 and $1 \% \mathrm{O}_{2}$ Conditions}

The effect of oxygen tension on proliferative capacity of subcultured CB- and PB-ECFCs was assessed at 20, 5, 2, and $1 \% \mathrm{O}_{2}$ cell culture conditions. Early passages (p2-p3) of CB- and PBECFCs obtained from the primary colonies at $20 \% \mathrm{O}_{2}$ cultures $(n$ $=3$ individual donors) were seeded at density of 500 cells $/ \mathrm{cm}^{2}$ on $0.1 \%$ gelatin coated cell culture vehicles in complete EGM2 and placed at $20,5,2$, and $1 \% \mathrm{O}_{2}$ incubators, respectively. Medium change of cultures placed at the corresponding $\mathrm{O}_{2}$ hypoxic chambers was performed as described in the previous section of material and methods.

Proliferation of subcultured ECFCs was calculated from cell counts. To that end, cells were incubated for indicated periods at different oxygen tensions. Subsequently they were washed, fixated with glutaraldehyde and their nuclei were stained by 
crystal violet. For each donor and time point/condition triplicate $10 \mathrm{~cm}^{2}$ wells were evaluated. From each stained well two pictures were taken at fixed positions (covering $60 \%$ of the plate surface), and the nuclei were counted using Image J software. Viability was determined by trypan blue exclusion after enzymatic detachment of unfixed cells (31). $\beta$-Galactosidase activity was assayed as previously indicated (31).

\section{Tube-Formation in Fibrin Matrix}

Assessment of sprouting ability of PB-ECFCs expanded in PLEGM was performed at $20 \% \mathrm{O}_{2}$ and $1 \% \mathrm{O}_{2}$ seeding 20,000 cells on $3 \mathrm{D}$ human fibrin matrices prepared as previously described (30). Following overnight incubation in M199 supplemented with $10 \%$ inactivated human serum and $10 \%$ new-born calf serum, tube formation was induced by stimulating the cells with the combination of $10 \mathrm{ng} / \mathrm{ml} \mathrm{TNF}-\alpha$ and $25 \mathrm{ng} / \mathrm{ml} \mathrm{VEGF} 165$ and refreshed after 2 days. All growth factors were purchased from ReliaTech GmbH, Wolfenbuttel, Germany. After $96 \mathrm{~h}$ stimulation, the cells were fixed with $2 \%$ paraformaldehyde/HBSS and quantification of the length of formed tube-like structures was performed using Optimas image analysis software as previously described (35). The tube formation ability of PBECFCs was determined in triplicate wells for each of 7 donors.

\section{RNA Isolation and Genome-Wide RNA-Sequencing}

To investigate the transcriptomic response of established $\mathrm{PB}$ ECFCs under hypoxia, cells from 6 female and 6 male donors were grown at $20 \% \mathrm{O}_{2}$ and exposed to $1 \% \mathrm{O}_{2}$ for $24 \mathrm{~h}$ in EBM-2 media (SingleQuots omitted) supplemented with 5\% platelet lysate prepared as previously described (31). The cell lysates were collected in $350 \mu \mathrm{L}$ per $20 \mathrm{~cm}^{2}$ cells of solution containing RLT buffer (Qiagen) $+10 \mu \mathrm{L} / \mathrm{mL} \beta$-mercaptanol. Mechanical disruption was accomplished using $1 \mathrm{~mL}$ syringes and $21 \mathrm{G}$ needles, and the cell lysates were stored at $-20^{\circ} \mathrm{C}$ overnight and transferred to $-80^{\circ} \mathrm{C}$ the next day. Total RNA was isolated using RNeasyMinElute Cleanup Kit (Qiagen, Netherlands) and the RNA quality was tested with a Nanodrop 1,000 spectrophotometer. An RNA pool for deep sequencing of $20 \% \mathrm{O}_{2}$ condition was prepared by mixing $2.5 \mu \mathrm{g}$ of RNA of each donor. The same procedure was repeated for preparing the pool of $1 \% \mathrm{O}_{2}$ RNA samples. The genome-wide RNA-sequencing was performed using the Illumina system accordingly to procedures described previously (36).

\section{Deep-Sequencing mRNA Analysis}

Statistical analysis of genome-wide RNA-sequencing data of the biological response of $\mathrm{PB}$-ECFCs during exposure to $1 \% \mathrm{O}_{2}$ for $24 \mathrm{~h}$ was performed using significance analysis of microarrays (SAM) (36). The genes were defined as significantly changed by a q-value of 0.05 and an $\mathrm{N}$-fold change $>1.5$ or $<0.66$. Only genes that complied to this double criteria were further analyzed using the online tools WEB-based GEne SeT AnaLysis Toolkit Webgestalt (37) and Gene Set Enrichment Analysis (GSEA, Broad Institute, United States). For visualization of proteinprotein interactions STRING10 analysis was used (38).

\section{Statistical Analysis}

Data on initial outgrowth of colonies from cord- or peripheral blood MNC are given as Mean \pm SD. Data on subcultured ECFCs are expressed as means \pm SEM. At least four independent experiments, with ECFCs isolated from different donors, were performed for all analyses, unless otherwise indicated. Single comparisons were made with Student's $t$ tests for normally distributed data or the Wilcoxon matched-pairs signed rank test for data not normally distributed. Comparisons between multiple groups were performed using one- or two-way ANOVA with Bonferroni post hoc test. Significance was defined as a $p<0.05$.

\section{RESULTS}

\section{Hypoxia Impairs the Initial Outgrowth of ECFCs From Cord Blood-Derived Mononuclear Cell Fraction}

The development of colonies of ECFCs from the MNC fraction of blood takes 10-14 days before they become visible and start to expand rapidly (also referred to as late-outgrowth EPCs). To investigate whether hypoxia stimulates the initial outgrowth of ECFCs from progenitor cells that reside within the MNC fractions of cord- and peripheral blood, CB-MNC inoculates of 14 individual donors were each incubated at $1 \%$ or $20 \% \mathrm{O}_{2}$ (both with $5 \% \mathrm{CO}_{2}$ ) for up to 30 days with regular renewal of the culture medium. The cultures were monitored daily for presence of colonies. ECFC colonies became detectable after 8-14 days and subsequently monitored and counted three times a week till the colonies started to merge. If no or only a few colonies were observed, the incubation was continued up to 30 days (to check for late coming colonies). The initial ECFC colonies were visible as densely packed cobblestone cell monolayers, which display VEcadherin and cortical F-actin staining and multiple cell divisions (Figures 1A-C). There was no differences in morphology or differences in immunohistochemical characterization between colonies obtained at $20 \%$ or $1 \%$ of oxygen (the last one shown in Figures 1A-C).

At $20 \% \mathrm{O}_{2}$, on average $13.9( \pm 8.5)$ colonies were obtained from cultures of CB-MNCs (Figure 1D; individual data in Supplemental Table 1). However, under $1 \% \mathrm{O}_{2}$ conditions 11 out of these $14 \mathrm{CB}-\mathrm{MNCs}$ generated no CB-ECFC colony outgrowth at all, while CB-ECFC outgrowth was limited to 2 colonies per isolation in the remaining 3 cultures. This failing in initiation of outgrowth resulted in a significant reduction $(p<$ 0.001 ) of the mean number of CB-ECFCs colonies per isolation from $13.9 \pm 8.5\left(20 \% \mathrm{O}_{2}\right)$ to $0.4 \pm 0.9\left(1 \% \mathrm{O}_{2}\right)$ (Figure 1D and Supplemental Table 1).

\section{Initial Clonal Outgrowth of PB-ECFCs in Hypoxia}

The initial outgrowth from PB-MNCs of nine individual adult donors also displayed a reduction in the number of ECFCs colonies developed in hypoxic PB-MNCs cultures as compared to their counterparts exposed to $20 \%$ oxygen levels. However, this effect was less extreme than in CB-ECFCs. Initiation of 

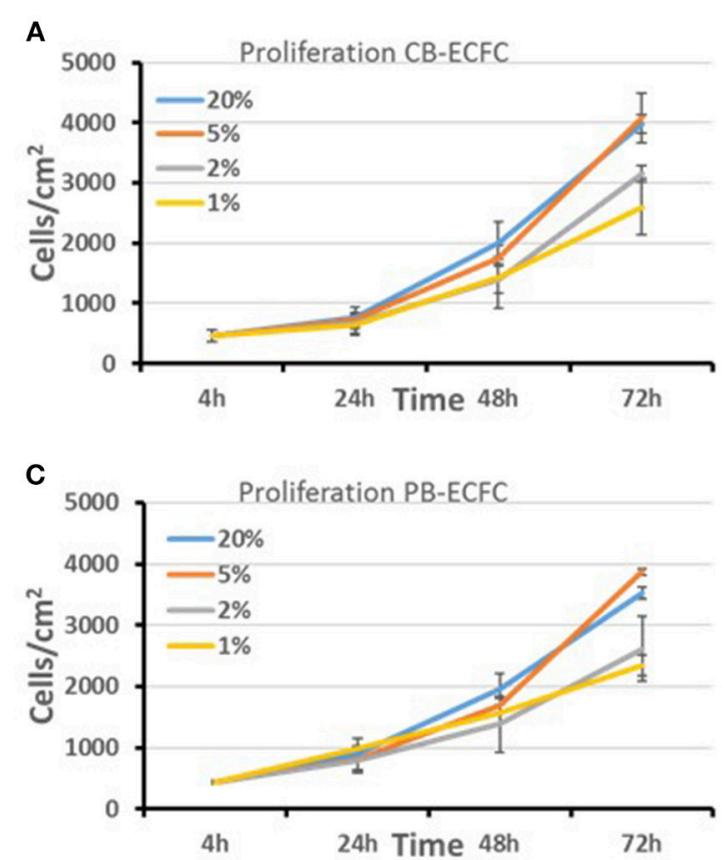
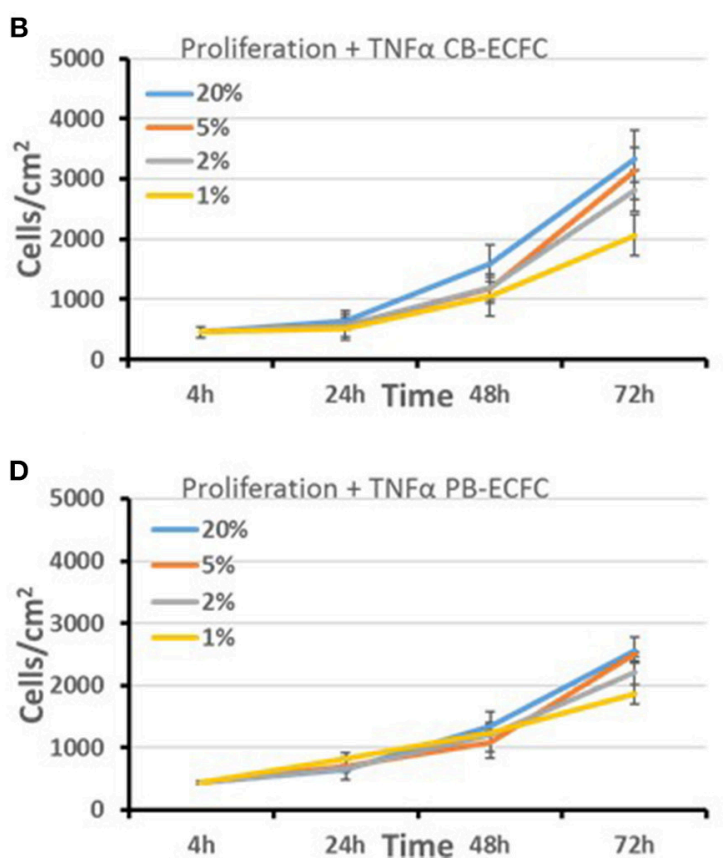

FIGURE 2 | Proliferation of subcultured CB and PB-ECFCs at various oxygen concentrations. The effect of oxygen concentration (20, 5, 2, and 1\%) in the absence $(\mathbf{A}, \mathbf{C})$ or presence of $10 \mathrm{ng} / \mathrm{ml}$ TNF $\alpha$ (B,D) on the proliferation rate of subcultured CB-ECFCs, expressed as mean number of cells/cm ${ }^{2}$ of 3 CB-ECFC and 3 $\mathrm{PB}-\mathrm{ECFC}$ isolations of different donors \pm SEM, is shown.

outgrowth was observed in 6 out of 9 ( $=66 \%$ of total isolations) resulting in a significant $(p<0.05)$ reduction of the mean number of ECFCs colonies per isolation from $4.7 \pm 3.4\left(20 \% \mathrm{O}_{2}\right)$ to 1.4 $\pm 1.7\left(1 \% \mathrm{O}_{2}\right)$ (Figure 1E and Supplemental Table 1). At the end of the colony isolation and outgrowth period of 30 days three times more colonies were counted in normoxic than in hypoxic cultures. However, those colonies that developed at $1 \%$ $\mathrm{O}_{2}$ also expanded rapidly, close to those that developed at $20 \%$ $\mathrm{O}_{2}$. Although PB-ECFCs are less sensitive to the outgrowth arrest observed with CB-ECFCs, our data indicate that hypoxia by itself is not suitable to speed up the clonal outgrowth of initial ECFC colonies.

\section{Effect of Oxygen Atmosphere on the Proliferation of Subcultured ECFCs}

To evaluate whether a decrease in cell division rate could explain the lack of initial colony outgrowth we cultured already established CB-ECFCs and PB-ECFCs at low density in various oxygen atmospheres and assayed their proliferation during their logarithmic growth phase (Figures 2A,C). For each of these conditions the oxygen atmosphere $(1,2,5$, and 20\%) was maintained during all manipulations, including microscopic inspection of cells and renewal of medium, which was prebalanced at the appropriate $\mathrm{O}_{2}$ atmosphere (30). From the obtained proliferation data we calculated the number of divisions and cell duplication time. As a colony of 32 cells is easily detectable during initial outgrowth assay and the division time of CB-ECFCs is 1.18- to 1.30-fold faster for cells in $20 \% \mathrm{O}_{2}$ than in $1 \% \mathrm{O}_{2}$, a reduced proliferation can (partly) contribute to but does not explain the lack or reduction of initial colony formation by CB-ECFCs and PB-ECFCs, respectively. Furthermore, the proliferation rates of $\mathrm{CB}$ - and PB-ECFCs in 20 and $1 \% \mathrm{O}_{2}$ are comparable and do not explain the fully impaired initial colony outgrowth in CB-ECFCs. Since inflammation is an important factor during angiogenesis and thereby also involved in the (out) growth of ECFCs, we evaluated the effect of the inflammatory mediator $\mathrm{TNF} \alpha$ on proliferation of subcultured ECFCs. TNF $\alpha$ reduced the proliferation rate of ECFCs independent of the oxygen concentrations (compare Figures 2A,B, and Figures 2C,D, respectively).

\section{Prior Exposure to Oxygen Overcomes Hypoxia-Induced Impairment of Initial CB-ECFC Outgrowth}

We hypothesized that the precursors of PB-ECFCs in the MNC fraction have been circulating in the blood, while those of CBECFCs may be released recently from the umbilical cord and less exposed to the oxygenated blood. Therefore, we evaluated whether temporal exposure of freshly isolated CB-MNCs to $20 \%$ oxygen contributed to the initiation of the process of ECFC colony formation by CB cells. To that end, freshly isolated CBMNC fractions of three donors were seeded and exposed for varying periods $(0-24-48-72-96 \mathrm{~h})$ to ambient oxygen $(20 \%$ $\mathrm{O}_{2}$ ) before transferred to $1 \% \mathrm{O}_{2}$ atmosphere for an additional hypoxic culture up to 4 weeks. Colony formation was monitored during this 4 weeks of culturing and compared to colony generation while exposed continuously to $20 \%$ oxygen. Figure 3 
A

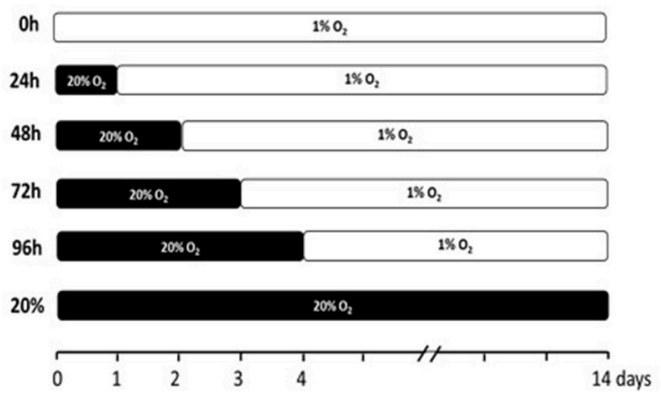

B

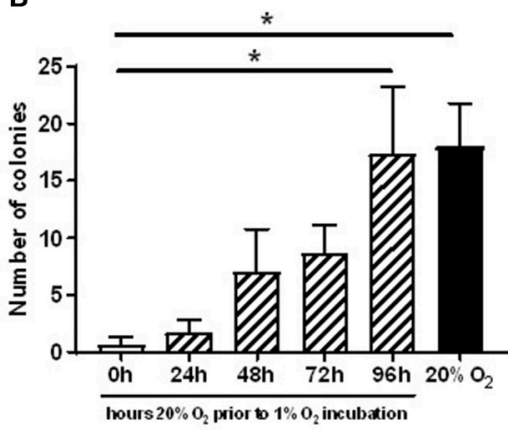

FIGURE 3 | Prior exposure to $20 \% \mathrm{O}_{2}$ restores the induction of ECFC colony formation in $1 \% \mathrm{O}_{2}$. The graph depicts enumeration of ECFC colony outgrowth from umbilical cord blood-derived MNCs. (A) The freshly isolated CB-MNC fractions of three donors were seeded and exposed for varying periods (0-96 h) to ambient oxygen $\left(20 \% \mathrm{O}_{2}\right)$ and subsequently transferred to $1 \% \mathrm{O}_{2}$ atmosphere for additional culture $\mathbf{( B )}$ ECFC colony outgrowth from umbilical cord blood-derived MNCs obtained from three different donors after 24,48 , 72 , or $96 \mathrm{~h}$ exposure to $20 \% \mathrm{O}_{2}$. Cells cultured only in $20 \% \mathrm{O}_{2}(20 \%)$, or $1 \% \mathrm{O}_{2}(\mathrm{O}$ h) served as controls. ECFC colonies were quantified when the colonies had become visible in the culture in $20 \% \mathrm{O}_{2}$ and expressed as average number \pm SEM $(n=3)$ of counted colonies. Statistical significance was determined by a One-way ANOVA with Bonferroni post-hoc test; ${ }^{*} p<0.05$.
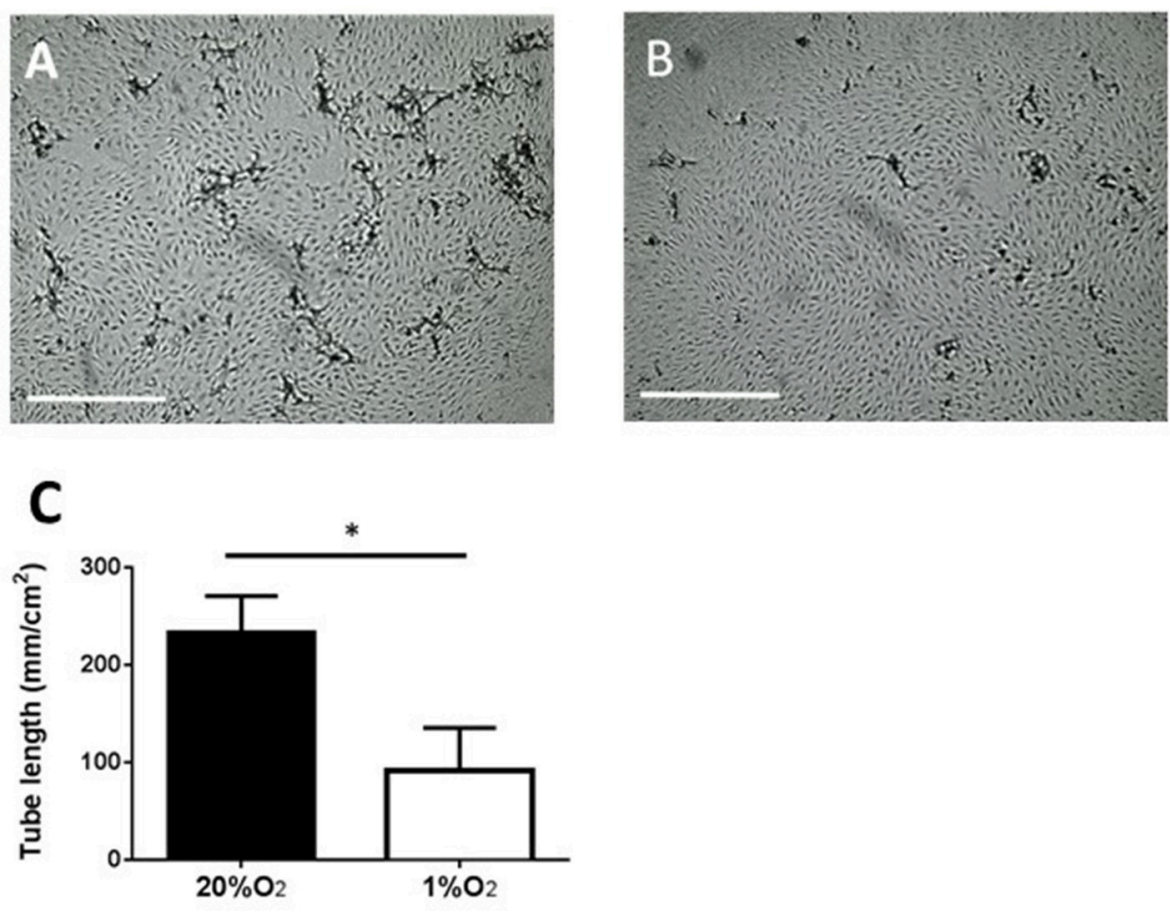

FIGURE 4 | Inhibition of tube-forming capacity of PB-ECFCs when cultured at $1 \% \mathrm{O}_{2}$. PB-ECFCs obtained from different donors were serially expanded in medium supplemented with PL at 20 or $1 \%$ of oxygen for 7 days. The PB-ECFCs were then seeded on 3D fibrin matrices and the sprouting ability of cells in fibrin matrices was then assessed after stimulation with the combination of $10 \mathrm{ng} / \mathrm{ml} \mathrm{TNF} \alpha$ and $25 \mathrm{ng} / \mathrm{ml} \mathrm{VEGF}$ at $20 \% \mathrm{O}_{2}$ (phase contrast picture A) or $1 \% \mathrm{O}_{2}$ (phase contrast picture B) for a period of $96 \mathrm{~h}$ (bar $=1,000 \mu \mathrm{m})$. Results represent the mean $\pm \mathrm{SEM}(n=7)$ of the length of tube-like structures of the donors (C) Statistical significance between two oxygen concentration conditions was determined by unpaired $t$-test; ${ }^{*} p<0.05$ ).

shows that subsequent to 2-3 days of $20 \% \mathrm{O}_{2}$ pre-exposure, but not shorter, initial outgrowth of ECFC colonies occurred in hypoxia. This reached statistical significance after 4 days (mean of 18 colonies in $20 \%$ of oxygen and mean of 17 colonies after 4 days of priming at $20 \% \mathrm{O}_{2}$ and subsequent $1 \% \mathrm{O}_{2}$ incubation). The subsequent expansion of these primed colonies proceeded fast, suggesting that the prior exposure to $20 \% \mathrm{O}_{2}$ largely overcame the growth arrest during the initial incubation period.

In agreement with previous findings (24) and similar to in other types of endothelial cells, exposure of CB-ECFCs to hypoxia induced both HIF-1 $\alpha$ and HIF- $2 \alpha$ (Supplemental Image 1). Transient deletion of the combination of HIF- $1 \alpha$ and HIF- $2 \alpha$ residues by siRNA, which lasted for at least $72 \mathrm{~h}$ (30), did 

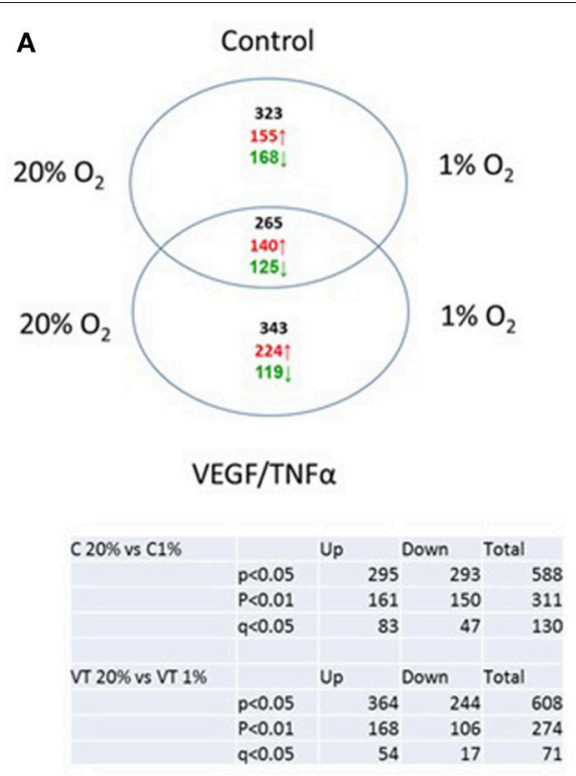
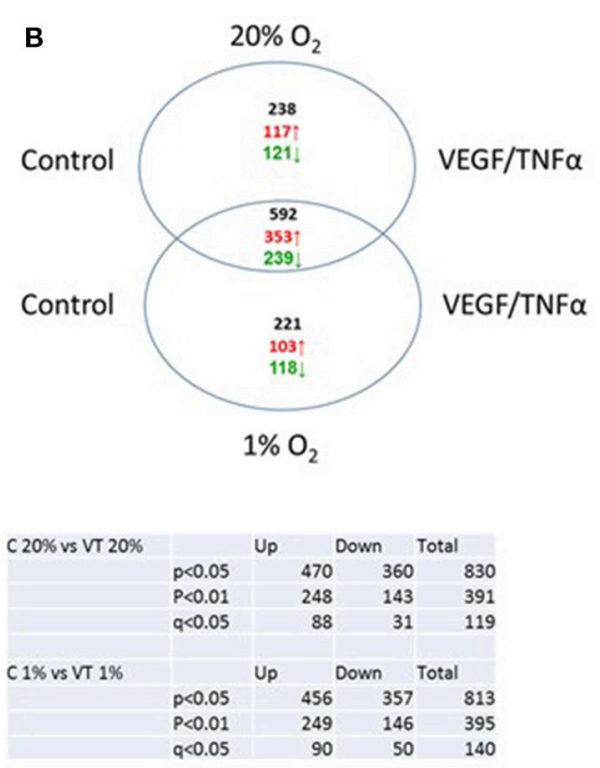

FIGURE 5 | Venn diagram of genes upregulated of downregulated in control (A) and VEGF/TNF $\alpha$-stimulated (B) PB-ECFCs.

also overcome the hypoxia-induced outgrowth arrest of ECFC colonies, similar to $20 \% \mathrm{O}_{2}$ exposure (Supplemental Image 2, Supplemental Table 1 independent experiments, however each with low number of colonies).

\section{Endothelial Tube Formation by PB-ECFCs at 1 and $20 \%$ Oxygen}

Subsequently, we focused on PB-ECFCs, as their autologous nature makes them the preferential ECFC type in tissue engineering applications. For an angiogenic response endothelial cells and ECFCs not only require proliferation, but also have to form tubular structures (sprouts) that invade into the hypoxic tissue. Exposure of monolayers of PB-ECFCs on top of a 3D fibrin matrix to the combination of VEGF/TNF $\alpha$ indeed induced endothelial tubule invasion in the fibrin matrix when cultured in the presence of $20 \% \mathrm{O}_{2}$. However, similar as earlier observed with human microvascular endothelial cells (30), the continuous exposure to $1 \%$ hypoxia during sprout formation significantly inhibited (59\% reduction compared to PB-ECFCs at $20 \% \mathrm{O}_{2}$, $p<0.05)$ tubule outgrowth from the PB-ECFC monolayer (Figure 4). At $20 \% \mathrm{O}_{2}$, tubule formation in fibrin fully depends on the availability of $\mathrm{u}-\mathrm{PA}$ and $\mathrm{uPAR}$, which indicates that migration/invasion plays a pivotal role $(33,34)$. On the other hand, the effect of hypoxia on proliferation of subcultured PBECFCs was limited-also after TNF $\alpha$-stimulation (Figure 2D), and may contribute only in a limited way to the reduction of tube formation. These effects reflect earlier findings in human microvascular endothelial cells (30).

\section{Gene Array Analysis of Hypoxic Response of Subcultured PB-ECFCs}

While HIF-1 $\alpha$ enhances endothelial sprouting, HIF- $2 \alpha$ has been suggested to stabilize endothelial tubules and limits endothelial sprouting (29). We recently identified by siRNA screen four HIF-2 $\alpha$-regulated genes that inhibited endothelial sprouting during prolonged hypoxia: ARRDC3, MME, PPARG, and RALGPS2 (36). To evaluate whether these genes were also regulated during the response of PB-ECFCs to hypoxia, we analyzed gene expression of a pool of 10 subcultured PB-ECFCs (from 5 male and 5 female donors) that were exposed for $24 \mathrm{~h}$ to $20 \% \mathrm{O}_{2}$ or $1 \% \mathrm{O}_{2}$, both in control and in VEGF/TNF $\alpha$-stimulated conditions as tubule formation was induced by the simultaneous exposure to VEGF-A and $\mathrm{TNF} \alpha$. Figure 5 summarizes the differential gene expression at the $p<0.05, p<0.01$, and $q<0.05$ levels as revealed by genome-wide RNA-sequencing. It shows that in control and VEGF/TNF $\alpha$-stimulated PB-ECFCs hypoxia altered the expression of 588 and 608 genes, respectively $(p<0.05)$. From these gene populations making up together 931 genes only 265 overlapped (140 up- and 125 down-regulated) (Figure 5). When the effects of VEGF/TNF $\alpha$ exposure was compared in ECFCs exposed to 1 or $20 \% \mathrm{O}_{2}$, the overlap accounted 592 out of a total of 1041 genes (Figure 5). The top 25 up and down regulated genes $(q<0.05)$ are shown in Tables 1A-D, and all the genes $(p<0.05)$ are listed in Supplemental Data Sheets 1, 2. Pathway analysis using the online tools Gene Set Enrichment Analysis (GSEA) and the WEB-based GEne SeT AnaLysis Toolkit (Webgestalt) revealed that the upregulated genes by hypoxia showed an enrichment in several metabolic pathways (see Figure 6B) including amino acid metabolisms, glycolysis/gluconeogenesis, and carbon-, fructoseand mannose metabolism. The downregulated genes were categorized mainly in cell cycle (Figure 6B), p53 signaling pathway and cytokine-cytokine receptor interactions (Table 2). The major regulated pathways were enriched in both control and VT-treated PB-ECFCs. These data comply with anticipated 
TABLE 1A | Top $(q<0.05) 25$ Up regulated genes by hypoxia (non-stimulated PB-ECFCs).

\begin{tabular}{|c|c|c|}
\hline $\begin{array}{l}\text { Gene } \\
\text { symbol }\end{array}$ & $n$-fold & Name \\
\hline PIK3R6 & 107,9 & $\begin{array}{l}\text { phosphoinositide-3-kinase, regulatory } \\
\text { subunit } 6\end{array}$ \\
\hline MIR210HG & 22,48 & MIR210 host gene (non-protein coding) \\
\hline ANGPTL4 & 17,06 & angiopoietin-like 4 \\
\hline GDF6 & 16,87 & growth differentiation factor 6 \\
\hline SYTL2 & 16,32 & synaptotagmin-like 2 \\
\hline PROM1 & 15,77 & prominin 1 \\
\hline VEGFA & 12,62 & vascular endothelial growth factor A \\
\hline ENO2 & 10,35 & enolase 2 (gamma, neuronal) \\
\hline SLC2A1 & 10,02 & $\begin{array}{l}\text { solute carrier family } 2 \text { (facilitated glucose } \\
\text { transporter), member } 1\end{array}$ \\
\hline INHBA & 10 & inhibin, beta A \\
\hline DNAH8 & 9,74 & dynein, axonemal, heavy chain 8 \\
\hline ADM2 & 9,19 & adrenomedullin 2 \\
\hline FBLN2 & 8,85 & fibulin 2 \\
\hline STC2 & 8,82 & stanniocalcin 2 \\
\hline ELN & 8,4 & Elastin \\
\hline \multirow[t]{2}{*}{ GALNTL2 } & 7,58 & $\begin{array}{l}\text { UDP-N-acetyl-alpha-D- } \\
\text { galactosamine:polypeptide }\end{array}$ \\
\hline & & N-acetylgalactosaminyltransferase-like 2 \\
\hline PODN & 7,11 & Podocan \\
\hline FER1L4 & 6,35 & fer-1-like 4 (C. elegans) pseudogene \\
\hline ALDOC & 6,13 & aldolase C, fructose-bisphosphate \\
\hline AK4 & 6 & adenylate kinase 4 \\
\hline NPTX1 & 5,92 & neuronal pentraxin I \\
\hline SDC2 & 5,38 & syndecan 2 \\
\hline SMAD7 & 5,37 & SMAD family member 7 \\
\hline TGFBI & 5,29 & $\begin{array}{l}\text { transforming growth factor, beta-induced, } \\
68 \mathrm{kDa}\end{array}$ \\
\hline ALDH1L2 & 5,28 & $\begin{array}{l}\text { aldehyde dehydrogenase } 1 \text { family, } \\
\text { member } L 2\end{array}$ \\
\hline
\end{tabular}

roles for cell division and metabolic control in the behavior of subcultured ECFCs in hypoxia.

Next, we looked at individual genes that were significantly altered by hypoxia and that were suggested earlier to contribute to endothelial sprouting. VEGF-A (as a positive regulator of angiogenesis) and ARRDC3 (negative regulator) were both significantly increased $(p<0.05 ; q<0.05)$ in control (12.6and 4.7-fold, respectively) and VEGF/TNF $\alpha$-exposed cells (4.0and 2.7-fold, respectively). MME and PPARG increased 2.2and 1.9-fold in hypoxic control ECFCs ( $p<0.05$, q ns), while their mRNAs were increased by 3.2- and 9.3-fold in VEGF/TNF $\alpha$-exposed ECFCs. No changes were observed in the expression of RALGPS-2. While the increase in VEGF-A may have little additional effect on cells that were already stimulated by VEGF/TNF $\alpha$, changes in VEGFRs probably do. VEGFR2 decreased consistently in hypoxia-treated cells, i.e., by $50 \%$ and $51 \%$ in control and VEGF/TNF $\alpha$-treated cells, respectively $(p<$
TABLE 1B | Top $(q<0.05) 25$ Up regulated genes by hypoxia (VT-stimulated PB-ECFCs).

\begin{tabular}{|c|c|c|}
\hline Gene symbol & $n$-fold & Name \\
\hline EGLN3 & 61,41 & egl nine homolog 3 (C. elegans) \\
\hline NUPR1 & 13,83 & nuclear protein, transcriptional regulator, 1 \\
\hline FABP3 & 12,52 & $\begin{array}{l}\text { fatty acid binding protein } 3, \text { muscle and } \\
\text { heart (mammary-derived growth inhibitor) }\end{array}$ \\
\hline PPARG & 9,30 & $\begin{array}{l}\text { peroxisome proliferator-activated receptor } \\
\text { gamma }\end{array}$ \\
\hline TGFBI & 9,22 & $\begin{array}{l}\text { transforming growth factor, beta-induced, } \\
68 \mathrm{kDa}\end{array}$ \\
\hline DNER & 7,56 & delta/notch-like EGF repeat containing \\
\hline SLC8A3 & 7,23 & $\begin{array}{l}\text { solute carrier family } 8 \text { (sodium/calcium } \\
\text { exchanger), member } 3\end{array}$ \\
\hline SYTL2 & 6,43 & synaptotagmin-like 2 \\
\hline HIF3A & 6,38 & hypoxia inducible factor 3 , alpha subunit \\
\hline ANGPTL4 & 6,16 & angiopoietin-like 4 \\
\hline COL25A1 & 5,05 & collagen, type XXV, alpha 1 \\
\hline PHGDH & 4,95 & phosphoglycerate dehydrogenase \\
\hline NDRG1 & 4,81 & N-myc downstream regulated 1 \\
\hline ENO2 & 4,65 & enolase 2 (gamma, neuronal) \\
\hline ADM2 & 4,65 & adrenomedullin 2 \\
\hline CSPG5 & 4,48 & $\begin{array}{l}\text { chondroitin sulfate proteoglycan } 5 \\
\text { (neuroglycan C) }\end{array}$ \\
\hline JDP2 & 4,39 & Jun dimerization protein 2 \\
\hline GPNMB & 4,38 & glycoprotein (transmembrane) nmb \\
\hline KLF4 & 4,28 & Kruppel-like factor 4 (gut) \\
\hline VEGFA & 3,99 & vascular endothelial growth factor A \\
\hline NPTX1 & 3,94 & neuronal pentraxin I \\
\hline SLC2A1 & 3,88 & $\begin{array}{l}\text { solute carrier family } 2 \text { (facilitated glucose } \\
\text { transporter), member } 1\end{array}$ \\
\hline MEGF6 & 3,83 & multiple EGF-like-domains 6 \\
\hline MN1 & 3,82 & $\begin{array}{l}\text { meningioma (disrupted in balanced } \\
\text { translocation) } 1\end{array}$ \\
\hline COL8A2 & 3,72 & collagen, type VIII, alpha 2 \\
\hline
\end{tabular}

$0.05, \mathrm{q} \mathrm{ns})$. The $40 \%$ and $12 \%$ increases in VEGFR1 were not significant, but-together with the drop in VEGFR2 - are likely to decrease ECFC sprouting and/or proliferation. In control and VEGF/TNF $\alpha$-exposed cells, respectively, a $20 \%$ and $16 \%$ drop in PlGF mRNA [a negative regulator as pointed out by Hookham et al. (24)] remained statistically non-significant. in VEGF/TNF $\alpha$-exposed ECFCs. No changes were observed in the expression of RALGPS-2. ANGPL4, which was recently recognized as a Wnt signaling antagonist (39), HIF3A and EGLN3 (PDH-3), were strongly upregulated, particularly in VEGF/TNF $\alpha$ exposed ECFCs (all $p$ and $q<0.05$ ).

\section{DISCUSSION}

Data presented in this study indicate that hypoxia does not stimulate, but impairs the initial outgrowth of ECFC colonies from cord and peripheral blood. This inhibition is stronger in CB-ECFCs than in PB-ECFCs. In CB-ECFCs hypoxia causes an initial outgrowth arrest that could largely be overcome by a 3-4 
TABLE 1C | Top $(q<0.05) 25$ Down regulated genes by hypoxia (non-stimulated PB-ECFCs)

\begin{tabular}{|c|c|c|}
\hline Gene symbol & $n$-fold & Name \\
\hline PRND & $-22,49$ & prion protein 2 (dublet) \\
\hline APLNR & $-18,14$ & apelin receptor \\
\hline GJA4 & $-15,17$ & gap junction protein, alpha 4, 37 kDa \\
\hline INHBB & $-6,37$ & inhibin, beta B \\
\hline AQP1 & $-5,00$ & aquaporin 1 (Colton blood group) \\
\hline RPS17 & $-4,88$ & ribosomal protein S17 \\
\hline RPS17L & $-4,83$ & ribosomal protein S17-like \\
\hline CDC20 & $-4,28$ & cell division cycle 20 homolog (S. cerevisiae) \\
\hline LYVE1 & $-4,10$ & $\begin{array}{l}\text { lymphatic vessel endothelial hyaluronan } \\
\text { receptor } 1\end{array}$ \\
\hline NUF2 & $-4,02$ & $\begin{array}{l}\text { NUF2, NDC80 kinetochore complex } \\
\text { component, homolog (S. cerevisiae) }\end{array}$ \\
\hline HMMR & $-3,74$ & $\begin{array}{l}\text { hyaluronan-mediated motility receptor } \\
\text { (RHAMM) }\end{array}$ \\
\hline NQO1 & $-3,70$ & $\mathrm{NAD}(\mathrm{P}) \mathrm{H}$ dehydrogenase, quinone 1 \\
\hline UCP2 & $-3,63$ & $\begin{array}{l}\text { uncoupling protein } 2 \text { (mitochondrial, proton } \\
\text { carrier) }\end{array}$ \\
\hline CKAP2L & $-3,62$ & cytoskeleton associated protein 2-like \\
\hline BUB1B & $-3,54$ & $\begin{array}{l}\text { budding uninhibited by benzimidazoles } 1 \\
\text { homolog beta (yeast) }\end{array}$ \\
\hline PAK6 & $-3,54$ & p21 protein (Cdc42/Rac)-activated kinase 6 \\
\hline PLK1 & $-3,52$ & polo-like kinase 1 \\
\hline ANLN & $-3,28$ & anillin, actin binding protein \\
\hline KIF4A & $-3,28$ & kinesin family member $4 \mathrm{~A}$ \\
\hline SHCBP1 & $-3,23$ & SHC SH2-domain binding protein 1 \\
\hline BIRC5 & $-3,21$ & baculoviral IAP repeat containing 5 \\
\hline TPX2 & $-3,16$ & $\begin{array}{l}\text { TPX2, microtubule-associated, homolog } \\
\text { (Xenopus laevis) }\end{array}$ \\
\hline SPAG5 & $-3,11$ & sperm associated antigen 5 \\
\hline KIFC1 & $-3,09$ & kinesin family member $\mathrm{C} 1$ \\
\hline CDCA8 & $-3,09$ & cell division cycle associated 8 \\
\hline
\end{tabular}

days pre-incubation in ambient air $\left(20 \% \mathrm{O}_{2}\right)$ before the explanted MNCs were transferred to the hypoxic atmosphere. Furthermore, the proliferation rate of subcultured CB- and PB-ECFCs was comparable at 5 and $20 \%$ oxygen, while it progressively dropped after exposure of the cells at $2 \%$ and $1 \% \mathrm{O}_{2}$, independent of a proliferation reducing effect of TNF $\alpha$. The ability of PB-ECFCs to form $\mathrm{VEGF} / \mathrm{TNF} \alpha$-induced tubules in a $3 \mathrm{D}$ - fibrin matrix was inhibited by hypoxia. These effects were accompanied by a marked change in the expression of genes, including cell cycle, metabolism controlling, and angiogenesis controlling genes.

\section{Initial Colony Formation in Hypoxia}

In agreement with most of these studies on CB-ECFCs, hypoxia reduced proliferation. A reduced proliferation will prolong the time period before initial colonies from explanted freshly isolated $\mathrm{CB}-\mathrm{MNC}$ become visible. However, the $18-30 \%$ reduction in proliferation rate that we found with subcultured CB-ECFCs is not sufficient to explain the absence of any ECFC clone after a 30 days evaluation period as seen in 11 out of 14 cultures. Other possibilities may regard a differentiation arrest of the progenitor
TABLE 1D | Top $(q<0.05) 17$ down regulated genes by hypoxia (VT-stimulated PB-ECFCs).

\begin{tabular}{|c|c|c|}
\hline Gene symbol & $n$-fold & Name \\
\hline CCL8 & $-23,88$ & chemokine (C-C motif) ligand 8 \\
\hline $\mathrm{C} 3$ & $-5,96$ & complement component 3 \\
\hline IL1B & $-4,88$ & interleukin 1 , beta \\
\hline KYNU & $-4,51$ & kynureninase \\
\hline EFNB2 & $-3,95$ & ephrin-B2 \\
\hline PLK1 & $-3,85$ & polo-like kinase 1 \\
\hline ADAMTS1 & $-3,79$ & $\begin{array}{l}\text { ADAM metallopeptidase with thrombospondin } \\
\text { type } 1 \text { motif, } 1\end{array}$ \\
\hline DLGAP5 & $-3,02$ & $\begin{array}{l}\text { discs, large (Drosophila) homolog-associated } \\
\text { protein } 5\end{array}$ \\
\hline CD200 & $-3,02$ & CD200 molecule \\
\hline CHST1 & $-2,95$ & $\begin{array}{l}\text { carbohydrate (keratan sulfate Gal-6) } \\
\text { sulfotransferase } 1\end{array}$ \\
\hline BUB1B & $-2,66$ & $\begin{array}{l}\text { budding uninhibited by benzimidazoles } 1 \\
\text { homolog beta (yeast) }\end{array}$ \\
\hline PAK6 & $-2,66$ & p21 protein (Cdc42/Rac)-activated kinase 6 \\
\hline TNFRSF11B & $-2,66$ & $\begin{array}{l}\text { tumor necrosis factor receptor superfamily, } \\
\text { member } 11 \mathrm{~b}\end{array}$ \\
\hline TOP2A & $-2,65$ & topoisomerase (DNA) II alpha $170 \mathrm{kDa}$ \\
\hline $\mathrm{BMX}$ & $-2,61$ & BMX non-receptor tyrosine kinase \\
\hline RRM2 & $-2,56$ & ribonucleotide reductase M2 \\
\hline MKI67 & $-2,44$ & antigen identified by monoclonal antibody Ki-67 \\
\hline
\end{tabular}

cells that develop into ECFC colonies or the loss of a positive interaction (or induction of a negative interaction) between hypoxic accessory MNCs and the endothelial progenitors. In preliminary experiments we could rule out the accumulation of soluble inhibitory factors as we did not find an effect of conditioned media taken from the hypoxic CB-MNC on the clonal outgrowth of subcultured CB-ECFCs. Furthermore, as 4 days pre-incubation in $20 \% \mathrm{O}_{2}$ or transient deletion of HIF- $1 \alpha$ and HIF- $2 \alpha$ was sufficient to overcome the lack of colony formation it is likely that a differentiation step is needed to "awake" the rapid proliferation of CB-ECFCs. As monocyte/macrophages also express HIF- $1 \alpha$ and HIF- $2 \alpha$ (40), we cannot discriminate yet whether such differentiation step is within the ECFC progenitors themselves or within the accompanying mononuclear monocytes.

Several lines of research pointed to an important effect of oxygen tension on cell differentiation (41, 42). Hypoxia reversibly arrested stem cells in an undifferentiated state (42), while low oxygen tensions have also been used to maintain the pluripotency of different progenitors (43). Therefore, it is not excluded that hypoxia by maintaining a quiescence phenotype of putative endothelial progenitor cells suppresses their endothelial differentiation toward ECFCs especially if the microenvironment is devoid of pro-neovascularization clues. It is plausible that in ischemic tissues-once the pro-angiogenic environment is established-growth factors that are essential for EC differentiation such as VEFG, FGF, or HGF in conjunction with pro-angiogenic myeloid cells such as circulating angiogenic cells would eventually overcome the hypoxia-induced inhibition of differentiation of EPCs toward EC phenotype. 


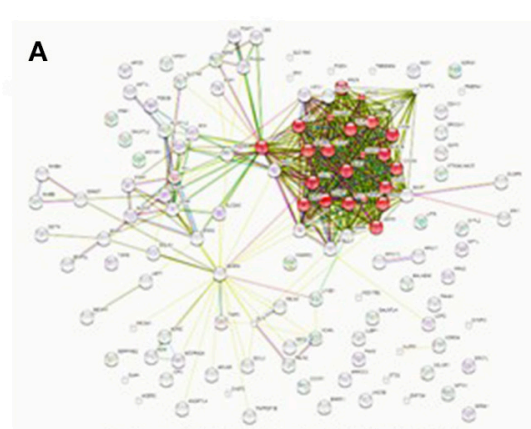

ALL: cell division (GO: 0051301)

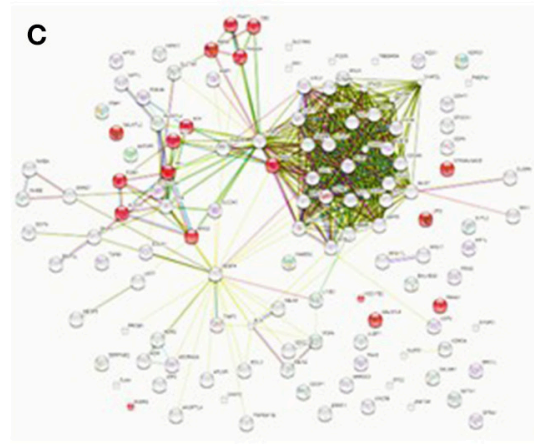

ALL: metabolic pathway (KEGG 01100)

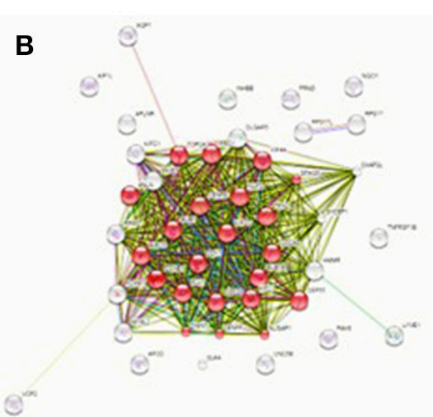

DOWN: cell division (GO: 0051301)

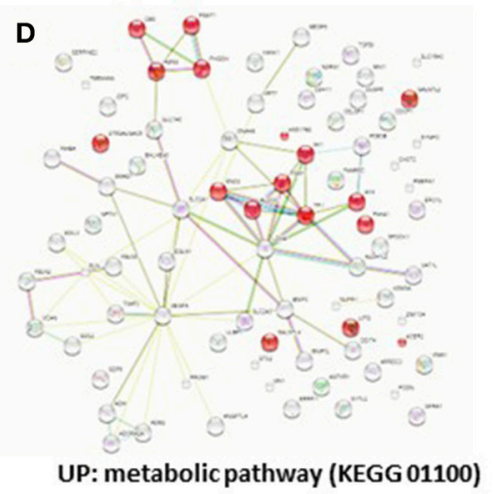

FIGURE 6 | Downregulation of cell cycle genes and upregulation of metabolic genes by hypoxia. Predicted protein-protein interactions show different protein clusters. Genes that were significantly differentially regulated (FDR $<5 \%$ in hypoxia $(\mathbf{A}, \mathbf{C})$, down-regulated (B) or upregulated in hypoxia (D) were clustered based on protein-protein interactions. The nodes represent the proteins and a shared function of the proteins are shown as interconnecting lines. The genes were clustered based on the GO (0051301) cell division pathway $\mathbf{( A , B )}$ or the KEGG (01100) metabolic pathway; genes involved in these pathways are indicated in red.

The initial outgrowth of PB-ECFCs was also inhibited by hypoxia, but to a much lesser extent than that of CB-ECFCs. The difference in the ability of CB-MNCs and PB-MNCs to generate primary clones under normoxia and hypoxia suggests that beside oxygen tension other factors play an important role in the initial outgrowth of ECFCs from MNCs. The microenvironment which imprint stem and progenitor cells during fetal and postnatal life can accounted for by observed differences between CB-MNCs and PB-MNCs in their ability to generate ECFCs colonies. Furthermore, to the best of our knowledge, there is no information about the circulation time of CB- and PB-endothelial progenitors. Hence, we cannot exclude that $\mathrm{PB}$-endothelial progenitors have been exposed to the oxygenated milieu of the blood for a longer period than their $\mathrm{CB}$ counterparts. Once isolated and cultured, ECFCs obtained from umbilical cord blood differ from PB-ECFCs with respect to proliferation (43) gene expression (44-46), and in vivo vessel formation $(46,47)$.

\section{Hypoxia and the Propagation of Subcultured ECFCs}

Hypoxia not only inhibited the initial outgrowth of ECFCs from CB- and PB-MNCs but also has an impact to the clonal and proliferative ability of subcultured cells. Interestingly, the CBECFCs displayed a small reduced proliferation at $1 \% \mathrm{O}_{2}$ which is in agreement with previously reports $(23,24)$, while similar data have also been reported very recently on PB-ECFCs (25). The whole genome sequencing data also showed a change in metabolic pathways and in cell cycle genes during exposure to hypoxia comparable with that of human foreskin MVECs (36). While the metabolic adaptation helps the cell to overcome the limitation of energy supply, the suppression of cell cycle genes likely contributes to the hypoxia-induced reduction of ECFC proliferation. Hypoxia-driven HIF- $1 \alpha$ activation with subsequent proliferation cell cycle arrest in G1/S phase and induction of apoptosis has been reported as a mechanism that restricts the growth of EC obtained from post-natal tissues (48). Whatever is the transcriptomic background of observed hypoxia-induced cell proliferation in CB- and PB-ECFCs, future investigation is warranted.

During neovascularization, ECFC proliferation matches the growth of the vascular tree. Our finding that hypoxia reduces ECFC proliferation is contra-intuitive suggesting that other factors that play a crucial role during in vivo neovascularization and are accountable for proper in vivo multiplication of $\mathrm{EC}$ are absent in our in vitro hypoxic assay. Indeed, rapid neovascularization reported in animal studies of addition of VEGF to ECFCs (49) as well as co-implantation of ECFCs with myeloid cells (50) or MSCs (51) pinpoint to the necessity to include these clues during in vitro assaying in order to unravel the true behavior of ECFCs under hypoxia. 
TABLE 2 | Hypoxia pathway analysis.

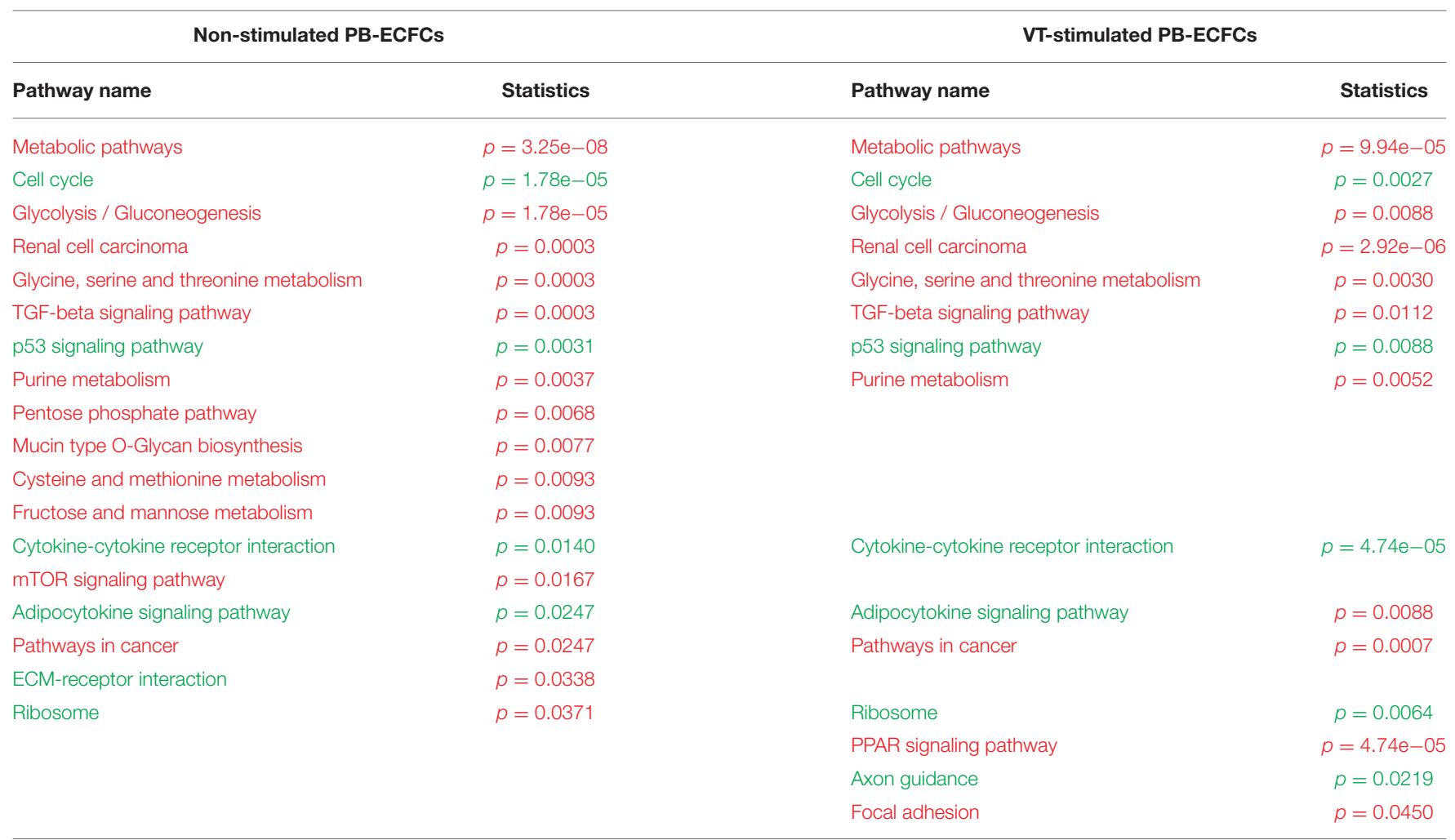

The KEGG pathways involved in angiogenesis and metabolism with a $p<0.05$ are show. Red is upregulated and green is downregulated.

\section{Endothelial Tube Formation by PB-ECFCs}

Hypoxia not only reduced proliferation, but also inhibited endothelial tube formation by PB-ECFCs into a fibrin matrix. This is in line with earlier observations on CB-ECFCs (22, 24). The observed inhibition of tube formation in hypoxia was highly similar to the inhibition observed in hypoxic human microvascular EC, which was largely corrected after inhibition of HIF-2 $\alpha(29,30)$. Hookham et al. (24) found that Placental growth factor (PlGF) was a major player in the inhibition of tube formation by hypoxic CB-ECFCs. How PlGF exerts its effect is not yet clear. As it binds to VEGFR-1 and NRP-1 (52), it may on the one hand prevent quenching of VEGF-A by VEGFR-1 (53), and at the other hand withdraw NRP-1 from assisting cis-oriented VEGFR-2 endocytosis which is required for VEGFR-2 signaling (54). Only the latter would contribute to inhibition of tubule formation. In our experimental conditions tubule formation was fully inhibited by anti-u-PA antibodies (33) or si-uPAR (34), which suggest that migration/invasion plays a dominant role in tube formation in the fibrin matrix. A comparable mechanism has been observed in tubule formation by human microvascular endothelial cells, a process that depended on migration/invasion independent of proliferation (35).

The suppression of ECFC sprouting and proliferation by hypoxia seems contra-intuitive, but it may reflects the monolayer stabilizing properties of endothelial cells induced by HIF- $2 \alpha$. This response normally balances the sprouting-inducing effect of
HIF-1 $\alpha$ (29). In an hypoxic environment the surrounding nonendothelial tissue cells mainly support the HIF- $1 \alpha$ part of this balance. However, the suggestion of a HIF- $2 \alpha$-suppressed ECFC sprouting contrasts to a very recent study of $\mathrm{He}$ et al. (25), who demonstrated by specific inhibition that inhibition of HIF- $1 \alpha$, but not HIF- $2 \alpha$, could overcome the hypoxia-induced inhibition of angiogenesis. This conclusion, which is opposite to studies on microvascular endothelial cells $(29,30)$, needs further evaluation and underpinning.

Altogether, there is firm consensus that hypoxia suppresses proliferation and sprouting of $\mathrm{CB}-$ and $\mathrm{PB}-\mathrm{ECFCs}$ in vitro, but how the variety of suggested mediators participate and interact requires further elucidation. Notwithstanding, the crucial question raised by our findings is "why is there poor outgrowth of circulating ECFCs in hypoxia, while expansion of endothelial cells would be essential for vessel repair or new vessel forming abilities in hypoxic conditions?" One cannot exclude that this reflects the fact that ECFCs were studied in isolation, while the presence of many hypoxic tissue cells may shift the balance more into pro-angiogenic direction. Alternatively, one may anticipate that the highly proliferation of ECFCs can in particular contribute to new vessels with improved tissue circulation at the interface of the hypoxic tissue and circulating blood. If non-perfused vessel-like structures would be made in the center of a chronic hypoxic environment, it would take much energy without improvement of blood and oxygen supply. However, under these conditions, alternative 
sources of "endothelial precursor cells" e.g., the quiescent resident endothelial cells in vessels (55) or endothelial cells derived from erythro-myeloid progenitors (56) might be involved. Getting more insight in all these alternatives is needed to improve the use of endothelial precursor cells and ECFCs in regenerative medicine.

\section{ETHICS STATEMENT}

The collection of cord and peripheral blood was approved and conducted according to the guidelines by the Medical Ethics Committee of the VU University medical center in Amsterdam, Netherlands.

\section{AUTHOR CONTRIBUTIONS}

DT prepared, performed and evaluated experiments (on PBECFCs) and made initial draft of the manuscript. LD-V

\section{REFERENCES}

1. Mustoe T. Understanding chronic wounds: a unifying hypothesis on their pathogenesis and implications for therapy. Am J Surg. (2004) 187:65S-70S. doi: 10.1016/S0002-9610(03)00306-4

2. Kellner K, Liebsch G, Klimant I, Wolfbeis OS, Blunk T, Schulz MB, et al. Determination of oxygen gradients in engineered tissue using a fluorescent sensor. Biotechnol Bioeng. (2002) 80:73-83. doi: 10.1002/bit.10352

3. Radisic M, Malda J, Epping E, Geng W, Langer R, Vunjak-Novakovic G. Oxygen gradients correlate with cell density and cell viability in engineered cardiac tissue. Biotechnol Bioeng. (2006) 93:332-43. doi: 10.1002/bit.20722

4. Levenberg S, Rouwkema J, Macdonald M, Garfein ES, Kohane DS, Darland DC, et al. Engineering vascularized skeletal muscle tissue. Nat Biotechnol. (2005) 23:879-84. doi: 10.1038/nbt1109

5. Santos MI, Reis RL. Vascularization in bone tissue engineering: physiology, current strategies, major hurdles and future challenges. Macromol Biosci. (2010) 10:12-27. doi: 10.1002/mabi.200900107

6. Laschke MW, Menger MD. Spheroids as vascularization units: from angiogenesis research to tissue engineering applications. Biotechnol Adv. (2017) 35:782-91. doi: 10.1016/j.biotechadv.2017.07.002

7. Frueh FS, Menger MD, Lindenblatt N, Giovanoli P, Laschke MW. Current and emerging vascularization strategies in skin tissue engineering. Crit Rev Biotechnol. (2017) 37:613-25. doi: 10.1080/07388551.2016.1209157

8. Asahara T, Murohara T, Sullivan A, Silver M, van der Zee R, Li T, et al. Isner: isolation of putative progenitor endothelial cells for angiogenesis. Science (1997) 275:964-7. doi: 10.1126/science.275.5302.964

9. Prater DN, Case J, Ingram DA, Yoder MC. Working hypothesis to redefine endothelial progenitor cells. Leukemia (2007) 21:1141-9. doi: $10.1038 /$ sj.leu.2404676

10. Timmermans F, Van Hauwermeiren F, De Smedt M, Raedt R, Plasschaert F, De Buyzere ML, et al. Endothelial outgrowth cells are not derived from CD133+ cells or CD45+ hematopoietic precursors. Arterioscler Thromb Vasc Biol. (2007) 27:1572-9. doi: 10.1161/ATVBAHA.107.144972

11. Yoder MC, Mead LE, Prater D, Krier TR, Mroueh KN, Li F, et al. Redefining endothelial progenitor cells via clonal analysis and hematopoietic stem/progenitor cell principals. Blood (2007) 109:1801-9. doi: 10.1182/blood-2006-08-043471

12. Tura O, Skinner EM, Barclay GR, Samuel K, Gallagher RC, Brittan M, et al. Late outgrowth endothelial cells resemble mature endothelial cells and are not derived from bone marrow. Stem Cells (2013) 31:338-48. doi: $10.1002 /$ stem. 1280

13. Medina RJ, Barber CL, Sabatier F, Dignat-George F, Melero-Martin JM, Khosrotehrani $\mathrm{K}$, et al. Endothelial progenitors: a consensus prepared, performed and evaluated experiments (on CBECFCs) and made initial draft of the manuscript. MvW performed experiments. HB was involved in supervising and evaluating experiments, corrected the manuscript. PK planned and supervised experiments, evaluated and assembled data, corrected the manuscript. $\mathrm{VvH}$ planned and supervised, final coordination of the manuscript.

\section{FUNDING}

This work was supported by Grant 1.6 of the Netherlands Institute for Regenerative Medicine (NIRM).

\section{SUPPLEMENTARY MATERIAL}

The Supplementary Material for this article can be found online at: https://www.frontiersin.org/articles/10.3389/fmed. 2018.00356/full\#supplementary-material statement on nomenclature. Stem Cells Transl Med. (2017) 6:1316-20. doi: $10.1002 /$ sctm.16-0360

14. Hirschi KK, Ingram DA, Yoder MC. Assessing identity, phenotype, and fate of endothelial progenitor cells. Arterioscler Thromb Vasc Biol. (2008) 28:1584-95. doi: 10.1161/ATVBAHA.107.155960

15. Ezashi T, Das P, Roberts RM. Low $\mathrm{O} 2$ tensions and the prevention of differentiation of hES cells. Proc Natl Acad Sci USA. (2005) 102:4783-8. doi: 10.1073/pnas.0501283102

16. Karigane D, Takubo K. Metabolic regulation of hematopoietic and leukemic stem/progenitor cells under homeostatic and stress conditions. Int J Hematol. (2017) 106:18-26. doi: 10.1007/s12185-017-2261-x

17. Weijers EM, Van Den Broek LJ, Waaijman T, Van Hinsbergh VW, Gibbs S, Koolwijk P. The influence of hypoxia and fibrinogen variants on the expansion and differentiation of adipose tissue-derived mesenchymal stem cells. Tissue Eng Part A (2011) 17:2675-85 doi: 10.1089/ten.tea.2010.0661

18. Hackenbeck T, Knaup KX, Schietke RJ, Schödel JC, Willam CX, Wu XC, et al. HIF-1 or HIF-2 induction is sufficient to achieve cell cycle arrest in NIH3T3 mouse fibroblasts independent from hypoxia. Cell Cycle (2009) 8:1386-95. doi: $10.4161 /$ cc.8.9.8306

19. Kumar S, Vaidya M. Hypoxia inhibits mesenchymal stem cell proliferation through HIF1 $\alpha$-dependent regulation of P27. Mol Cell Biochem. (2016) 415:29-38. doi: 10.1007/s11010-016-2674-5

20. Ceradini DJ, Kulkarni AR, Callaghan MJ, Tepper OM, Bastidas N, Kleinman $\mathrm{ME}$, et al. Progenitor cell trafficking is regulated by hypoxic gradients through HIF-1 induction of SDF-1. Nat Med. (2004) 10:858-64. doi: 10.1038/nm1075

21. Youn SW, Lee SW, Lee J, Jeong HK, Suh JW, Yoon CH, et al. COMP-Ang1 stimulates HIF- $1 \alpha$-mediated SDF-1 overexpression and recovers ischemic injury through BM-derived progenitor cell recruitment. Blood (2011) 117:4376-86. doi: 10.1182/blood-2010-07-295964

22. Zhang Y, Fisher N, Newey SE, Smythe J, Tatton L, Tsaknakis G, et al The impact of proliferative potential of umbilical cord-derived endothelial progenitor cells and hypoxia on vascular tubule formation in vitro. Stem Cells Dev. (2009) 18:359-75. doi: 10.1089/scd.2008.0071

23. Decaris ML, Lee CI, Yoder MC, Tarantal AF, Leach JK. Influence of the oxygen microenvironment on the proangiogenic potential of human endothelial colony forming cells. Angiogenesis (2009) 12:303-11. doi: 10.1007/s10456-009-9152-6

24. Hookham MB, Ali IH, O'Neill CL, Hackett E, Lambe MH, Schmidt T, et al. Hypoxia-induced responses by endothelial colony-forming cells are modulated by placental growth factor. Stem Cell Res Ther. (2016) 7:173. doi: 10.1186/s13287-016-0430-0

25. He M, Ma S, Cai Q, Wu Y, Shao C, Kong H, et al. Hypoxia induces the dysfunction of human endothelial colony-forming cells 
via HIF-1alpha signaling. Respir Physiol Neurobiol. (2018) 247:87-95. doi: 10.1016/j.resp.2017.09.013

26. Lee SH, Lee JH, Han YS, Ryu JM, Yoon YM, Han H. J. Hypoxia accelerates vascular repair of endothelial colony-forming cells on ischemic injury via STAT3-BCL3 axis. Stem Cell Res Ther. (2015) 6:139. doi: 10.1186/s13287-015-0128-8

27. Avouac J, Wipff J, Goldman O, Ruiz B, Couraud PO, Chiocchia G, et al. Angiogenesis in systemic sclerosis: impaired expression of vascular endothelial growth factor receptor 1 in endothelial progenitor-derived cells under hypoxic conditions. Arthritis Rheum. (2008) 58:3550-61. doi: 10.1002/art.23968

28. Kutscher C, Lampert FM, Kunze M, Markfeld-Erol F, Stark GB, and Finkenzeller G. Overexpression of hypoxia-inducible factor-1 alpha improves vasculogenesis-related functions of endothelial progenitor cells. Microvasc Res. (2016) 105:85-92. doi: 10.1016/j.mvr.2016.01.006

29. Skuli N, Majmundar AJ, Krock BL, Mesquita RC, Mathew LK, Quinn ZL et al. Endothelial HIF-2alpha regulates murine pathological angiogenesis and revascularization processes. J Clin Invest. (2012) 122:1427-43. doi: $10.1172 /$ JCI57322

30. Nauta TD, Duyndam MC, Weijers EM, van Hinsbergh VM, Koolwijk P. HIF-2alpha expression regulates sprout Formation into 3D fibrin matrices in prolonged hypoxia in human microvascular endothelial cells. PLoS ONE (2016) 11:e0160700. doi: 10.1371/journal.pone.0160700

31. Tasev D, van Wijhe MH, Weijers EM, van Hinsbergh VW, Koolwijk P. Longterm expansion in platelet lysate increases growth of peripheral blood-derived endothelial-colony forming cells and their growth factor-induced sprouting capacity. PLoS ONE (2015) 10:e0129935 doi: 10.1371/journal.pone.0129935

32. Lin Y, Weisdorf DJ, Solovey A, Hebbel RP. Origins of circulating endothelial cells and endothelial outgrowth from blood. J Clin Invest. (2000) 105:71-7. doi: 10.1172/JCI8071

33. van Beem RT, Verloop RE, Kleijer M, Noort WA, Loof N, Koolwijk P, et al. Blood outgrowth endothelial cells from cord blood and peripheral blood: angiogenesis-related characteristics in vitro. J Thromb Haemost. (2009) 7:217-26. doi: $10.1111 / j .1538-7836.2008 .03192 . x$

34. Tasev D, Konijnenberg LS, Amado-Azevedo J, van Wijhe MH, Koolwijk P, van Hinsbergh VW. CD34 expression modulates tubeforming capacity and barrier properties of peripheral blood-derived endothelial colony-forming cells (ECFCs). Angiogenesis (2016) 19:325-38. doi: 10.1007/s10456-016-9506-9

35. Koolwijk P, van Erck MG, de Vree WJ, Vermeer MA, Weich HA, Hanemaaijer R, et al. Cooperative effect of TNFalpha, bFGF, and VEGF on the formation of tubular structures of human microvascular endothelial cells in a fibrin matrix. Role of urokinase activity. J Cell Biol. (1996) 132:1177-88. doi: $10.1083 /$ jcb.132.6.1177

36. Nauta TD, van den Broek M, Gibbs S, van der Pouw-Kraan TC, Oudejans CB, van Hinsbergh, VW et al. Identification of HIF-2alpharegulated genes that play a role in human microvascular endothelial sprouting during prolonged hypoxia in vitro. Angiogenesis (2017) 20:39-54. doi: 10.1007/s10456-016-9527-4

37. Wang J, Duncan D, Shi Z, Zhang B. WEB-based GEne set analysis toolkit (WebGestalt): update 2013. Nucleic Acids Res. (2013) 41:W77-83 doi: $10.1093 /$ nar/gkt439

38. Szklarczyk D, Franceschini A, Wyder S, Forslund K, Heller D, Huerta-Cepas J, et al. STRING v10: protein-protein interaction networks, integrated over the tree of life. Nucleic Acids Res. (2015) 43:D447-52. doi: 10.1093/nar/gku1003

39. Kirsch N, Chang LS, Koch S, Glinka A, Dolde C, Colozza G, et al. Angiopoietin-like 4 is a Wnt signaling antagonist that promotes LRP6 Turnover. Dev Cell. (2017) 43:71-82.e6. doi: 10.1016/j.devcel.2017.09.011

40. Elbarghati L, Murdoch C, Lewis CE. Effects of hypoxia on transcription factor expression in human monocytes and macrophages. Immunobiology (2008) 213:899-908. doi: 10.1016/j.imbio.2008.07.016

41. Millman JR, Tan JH, Colton CK. The effects of low oxygen on self-renewal and differentiation of embryonic stem cells. Curr Opin Organ Transpl. (2009) 14:694-700. doi: 10.1097/MOT.0b013e3283329d53

42. Lin Q, Lee YJ, Yun Z. Differentiation arrest by hypoxia. J Biol Chem. (2006) 281:30678-83. doi: 10.1074/jbc.C600120200
43. Theus MH, Wei L, Cui L, Francis $\mathrm{K}, \mathrm{Hu} \mathrm{X}$, Keogh $\mathrm{C}$, et al. In vitro hypoxic preconditioning of embryonic stem cells as a strategy of promoting cell survival and functional benefits after transplantation into the ischemic rat brain. Exp Neurol. (2008) 210:656-70. doi: 10.1016/j.expneurol.2007. 12.020

44. Gremmels H, Fledderus JO, van Balkom BW, Verhaar MC. Transcriptome analysis in endothelial progenitor cell biology. Antioxid Redox Signal. (2011) 15:1029-42. doi: 10.1089/ars.2010.3594

45. Nuzzolo ER, Capodimonti S, Martini M, Iachininoto MG, Bianchi M, Cocomazzi A, et al. Adult and cord blood endothelial progenitor cells have different gene expression profiles and immunogenic potential. Blood Transfus. (2014) 12 (Suppl 1) s367-74. doi: 10.2450/2013.0042-13

46. Kim J, Jeon YJ, Kim HE, Shin JM, Chung HM, Chae JI. Comparative proteomic analysis of endothelial cells progenitor cells derived from cord blood- and peripheral blood for cell therapy. Biomaterials. (2013) 34:1669-85. doi: 10.1016/j.biomaterials.2012.11.017

47. Au P, Daheron LM, Duda DG, Cohen KS, Tyrrell JA, Lanning RM, et al. Differential in vivo potential of endothelial progenitor cells from human umbilical cord blood and adult peripheral blood to form functional long-lasting vessels. Blood (2008) 111:1302-5. doi: 10.1182/blood-2007-06094318

48. Yanyan C, Guoxian Q, Yang G, Leting W. Mechanism of hypoxia-induced factor 1alpha expression in endothelial cells of the human umbilical vein and its induction of apoptosis. Mol Biol Rep. (2008) 35:285-90. doi: 10.1007/s11033-007-9083-5

49. Kim PH, Yim HG, Choi YJ, Kang BJ, Kim J, Kwon SM, et al. Injectable multifunctional microgel encapsulating outgrowth endothelial cells and growth factors for enhanced neovascularization. J Control Rel. (2014) 187:113. doi: $10.1016 /$ j.jconrel.2014.05.010

50. Melero-Martin JM, De Obaldia ME, Allen P, Dudley AC, Klagsbrun M, Bischoff J. Host myeloid cells are necessary for creating bioengineered human vascular networks in vivo. Tissue Eng Part A (2010) 16:2457-66. doi: $10.1089 /$ ten.tea.2010.0024

51. Lin RZ, Moreno-Luna R, Zhou B, Pu WT, Melero-Martin JM. Equal modulation of endothelial cell function by four distinct tissuespecific mesenchymal stem cells. Angiogenesis (2012) 15:443-55. doi: $10.1007 / \mathrm{s} 10456-012-9272-2$

52. Dewerchin M, Carmeliet P. Placental growth factor in cancer. Expert Opin Ther Targets (2014) 18:1339-54. doi: 10.1517/14728222.2014. 948420

53. Meyer RD, Mohammadi M, Rahimi NN. A single amino acid substitution in the activation loop defines the decoy characteristic of VEGFR-1/FLT-1. J Biol Chem. (2006) 281:867-75. doi: 10.1074/jbc.M506454200

54. Koch S, van Meeteren LA, Morin E, Testini C, Weström S, Björkelund $\mathrm{H}$, et al. NRP1 presented in trans to the endothelium arrests VEGFR2 endocytosis, preventing angiogenic signaling and tumor initiation. Dev Cell (2014) 28:633-46. doi: 10.1016/j.devcel.2014.02.010

55. McDonald AI, Shirali AS, Aragon R, Ma F, Hernandez G, Vaughn DA, et al. Endothelial regeneration of large vessels Is a biphasic process driven by local cells with distinct proliferative capacities. Cell Stem Cells (2018) 23:210-25. doi: 10.1016/j.stem.2018.07.011

56. Plein A, Fantin A, Denti L, Pollard JW, Ruhrberg C. Erythro-myeloid progenitors contribute endothelial cells to blood vessels. Nature (2018) 52:223-30. doi: 10.1038/s41586-018-0552-x

Conflict of Interest Statement: The authors declare that the research was conducted in the absence of any commercial or financial relationships that could be construed as a potential conflict of interest.

Copyright (๑) 2018 Tasev, Dekker-Vroling, van Wijhe, Broxterman, Koolwijk and van Hinsbergh. This is an open-access article distributed under the terms of the Creative Commons Attribution License (CC BY). The use, distribution or reproduction in other forums is permitted, provided the original author(s) and the copyright owner(s) are credited and that the original publication in this journal is cited, in accordance with accepted academic practice. No use, distribution or reproduction is permitted which does not comply with these terms. 